Abstracta Iranica Abstracta Iranica

Revue bibliographique pour le domaine irano-aryen

Volume 32-33 | 2013

Comptes rendus des publications de 2009-2010

\title{
Éloïse Brac de la Perriere. Les tuniques talismaniques indiennes d'époque pré-moghole et moghole à la lumière d'un groupe de corans en écriture bihārī
}

\section{Fabrizio Speziale}

\section{(2) OpenEdition \\ 1 Journals}

\section{Édition électronique}

URL : http://journals.openedition.org/abstractairanica/40616

DOI : 10.4000/abstractairanica.40616

ISSN : 1961-960X

Éditeur :

CNRS (UMR 7528 Mondes iraniens et indiens), Éditions de l'IFRI

\section{Édition imprimée}

Date de publication : 1 décembre 2013

ISSN : 0240-8910

\section{Référence électronique}

Fabrizio Speziale, «Éloïse Brac de la Perriere. Les tuniques talismaniques indiennes d'époque prémoghole et moghole à la lumière d'un groupe de corans en écriture bihārī », Abstracta Iranica [En ligne], Volume 32-33 | 2013, document 267, mis en ligne le 01 juillet 2016, consulté le 27 septembre 2020. URL : http://journals.openedition.org/abstractairanica/40616 ; DOI : https://doi.org/10.4000/ abstractairanica.40616

Ce document a été généré automatiquement le 27 septembre 2020.

Tous droits réservés 


\title{
Éloïse Brac de la Perriere. Les
} tuniques talismaniques indiennes d'époque pré-moghole et moghole à la lumière d'un groupe de corans en écriture bihārī

\author{
Fabrizio Speziale
}

\section{RÉFÉRENCE}

Éloïse Brac de la Perriere. «Les tuniques talismaniques indiennes d'époque prémoghole et moghole à la lumière d'un groupe de corans en écriture bihārī ». Journal Asiatique, 297/1, 2009, p. 57-81.

Cet article analyse un groupe de tuniques talismaniques produites en Inde et précédemment datées de l'époque moghole. L'A. propose de revoir la datation de ces tuniques, qui furent probablement réalisées au cours de la période médiévale des sultanats pré-moghols. Comme le souligne l'A., la prépondérance du texte coranique et l'absence de figures magiques constituent l'une des principales caractéristiques des tuniques talismaniques réalisées en Inde. Cette nouvelle datation provient notamment des similitudes importantes que ces tuniques présentent avec un groupe de corans en écriture bihārī, ainsi qu'avec un rouleau magique, qui furent vraisemblablement réalisés entre la fin du XIV $\mathrm{e}$. et la fin du XVI ${ }^{\mathrm{e}}$ siècle. L'article est illustré par dix images en noir et blanc qui reproduisent les tuniques conservées au Musée Guimet et dans la collection Khalili, ainsi que deux pages de deux corans réalisés à l'époque des sultanats pré-moghols. 


\section{AUTEURS}

\section{FABRIZIO SPEZIALE}

Université Sorbonne Nouvelle-Paris 3 / Mondes iranien et indien, Paris 